\title{
ASSESSMENT OF SELECTED FOOD PRODUCTS FOR PESTICIDE RESIDUE IN MAJOR MARKETS OF OYO STATE, NIGERIA
}

\author{
Adesina Gabriel Olulakin ${ }^{a^{*}}$, Babarinde Samuel Adelani ${ }^{\mathrm{b}}$, \\ Olaniran Abiodun Oladele ${ }^{c}$ \\ Ladoke Akintola University of Technology, P. M. B. 4000, Ogbomoso, Nigeria. \\ E-mail address: aolulakinadesina@gmail.com, bsamdelani@yahoo.com, \\ coaolaniran@lautech.edu.ng
}

\begin{abstract}
Keywords: pesticide, pesticide residue, banned pesticide, yam, maize, cowpea, smoked fish
\end{abstract}
\begin{abstract}
A study was carried out on the assessment of selected food produce for pesticide residue in Oyo State. With the aid of multi stage sampling technique, 8 selected markets were surveyed in the major constituencies of Oyo State which included Oje and Bodija Market in Ibadan, Arada and Sabo Markets in Ogbomoso, Ajegunle and Araromi Market in Oyo, Owode and Sango Markets in Igboho and Saki respectively in Oke-Ogun. Information on type of pesticide use, reason for choosing the pesticide, method of applying the pesticide and duration of post application storage, were collected. Food produce sampled were yam chips, cowpea, maize and smoked fish for residual analysis. The residual analysis includes extraction of samples, cleaning of extraction and screening of the pesticide using GC-MS to detect any chemical metabolites.

The survey reveals that majority $(87.5 \%)$ of respondents were involved in selling of maize, yam chips and cowpea and the most used pesticide in the market was Aluminium phosphide marketed as phostoxin. Many of respondents applied pesticide by fumigation and the choice of these pesticides was base on customary practices. These food produce are stored for less than a month before being disposed of to consumers. Result from residual analysis shows sample from all the markets contains high percentage of alkane compounds especially the heptadecanes, eicosane, hexadecane and octadecane. Organochlorines were also found in the samples at high percentage.

Banned pesticides are still in use in the visited markets and the use of banned pesticide should be prohibited and extension scheme on the use of pesticide on stored produce should be sponsored by government. This will help educate pesticide users on the use of pesticides and its health implications. Consumers are also implored to wash their food very well before consumption so as to remove pesticides that may be present on the seed coat or surface of food produce.
\end{abstract}

\section{INTRODUCTION}

In the recent time, there has been news of food poisoning in many household in Nigeria. The bulk of the blame is laid on the farmers' table as the farming communities were been accused of using pesticides which are tagged to be dangerous to human health. Food storage plays an important role in the ability of any nation to feed its citizens, there is usually an abundance of food immediately after harvest, if appropriate storage has been perfected [1]. It is estimated that in the tropics between 25 and $40 \%$ of stored agricultural products is lost because of inadequate farm- and village-level storage every year [2]. In the field and during storage the products are threatened by insects, rodents, birds and other pests. These products may be spoiled by infection from fungi, yeasts or bacteria.

The United State Census Beaureu (USCB) estimates that the world population exceeds 7 billion on March 12, 2012. The world population is expected to become between 8.3 -10.9 billion by 2050 . The high population growth rate, particularly in the developing countries, and the changing diets will lead to a much higher food demand by 2050 [3]. To meet this increasing rise in population there is the need to store food product with pesticides to reduce losses due to pest.

The frequent incidence of pests in agricultural commodities such as insects, fungi, rodent etc, has a potential negative impact. This is because harvest and post- harvest techniques adequate for 
the prevention of pest infestation are seldom practiced coupled with inadequate storage facilities [4, 5].

Pesticides are an important management tool in agricultural enterprise, they protect produce against pests at post-harvest and storage, it has continued to be the bedrock of agriculture in modern times because of its unquantifiable benefits one of which include enhancement of shelf life of stored agricultural products [6].

[7] 2007 maintained that for every dollar spent on pesticide for crop yield and storage four dollars is saved. In Nigeria, insect related to post-harvest food losses are estimated at around 30\%, insects control have been by the use of synthetic insecticides which have adverse effects on human health and the undesirable consequences of pesticides use on human health have become more evident [8].

A global scale of acute poisoning by plant protection chemicals is not exactly known and all data are based on estimates. In 2002, the number of deaths due to acute poisoning by pesticides was estimated at about 220,000 annually, which represent only a small percentage of the total number of such poisonings of roughly 26 million a year [9]. The threat of the use of chemicals in agriculture is greatest in developing countries, since the awareness of the local population about the negative impact of pesticides on health is still relatively low. This is confirmed by recent research carried out in rural regions of Asia where the number of deaths due to pesticide poisoning is estimated at 300,000 cases a year [10].

Recently concern about the health effects of pesticides have increased over the years considering the rates at which scholars have put into the study of the phenomenon. Most often, scholars have written so much on the use of dangerous chemicals, banned pesticides, pesticide overdose, safe practices and the like but little has been written on the waiting period between application and consumption. This dearth of scholarly information is inexcusable, scarce resources and time have often been channelled to investigate other cause of pesticide contamination in stored produce, and the silence on withholding period which leaves residues that are poisonous to the consumer of the treated products.

For example it was reported that four out of a family of 9 died after eating yam flour treated with pesticides in Isua-Akoko Area of Ondo State, Nigeria. It was diagnosed at the Federal Medical Centre Owo, Nigeria, that they have eaten poison [11]. These adverse effects of pesticides are caused by pesticide abuse and misuse, a recent report indicated that two children died and 112 people were hospitalised after consuming cowpea treated with pesticide in Cross River state, test shows that the consequence is as a result of pesticide poisoning [12].

The presence of the pesticide residue is a concern for consumer because pesticides are known to have potential harmful effects to other non-target organisms than pests and disease. Exposing consumers to food items treated with pesticide before the chemical fully break down could pose a serious threat to health and life. Therefore, this work will looks into the types of pesticide used, reasons for choosing the pesticide, duration of storage before and after application as well as mode of application.

Therefore, the objectives of this study therefore are to evaluate the different types of pesticides used by market men and women to preserve selected agriculture produce and analyze these produce for chemical residues.

\section{MATERIALS AND METHODS}

\section{SURVEY AREA}

A survey was carried out in major markets in Oyo State which included Bodija and Oje Markets in Ibadan, Araada and Sabo Markets in Ogbomoso, Akeesan and Ajegunle Markets in Oyo, Sango Market in Saki, and Owode market in Igboho. The selected markets were known for storage and merchandise of agricultural produce in the state. 


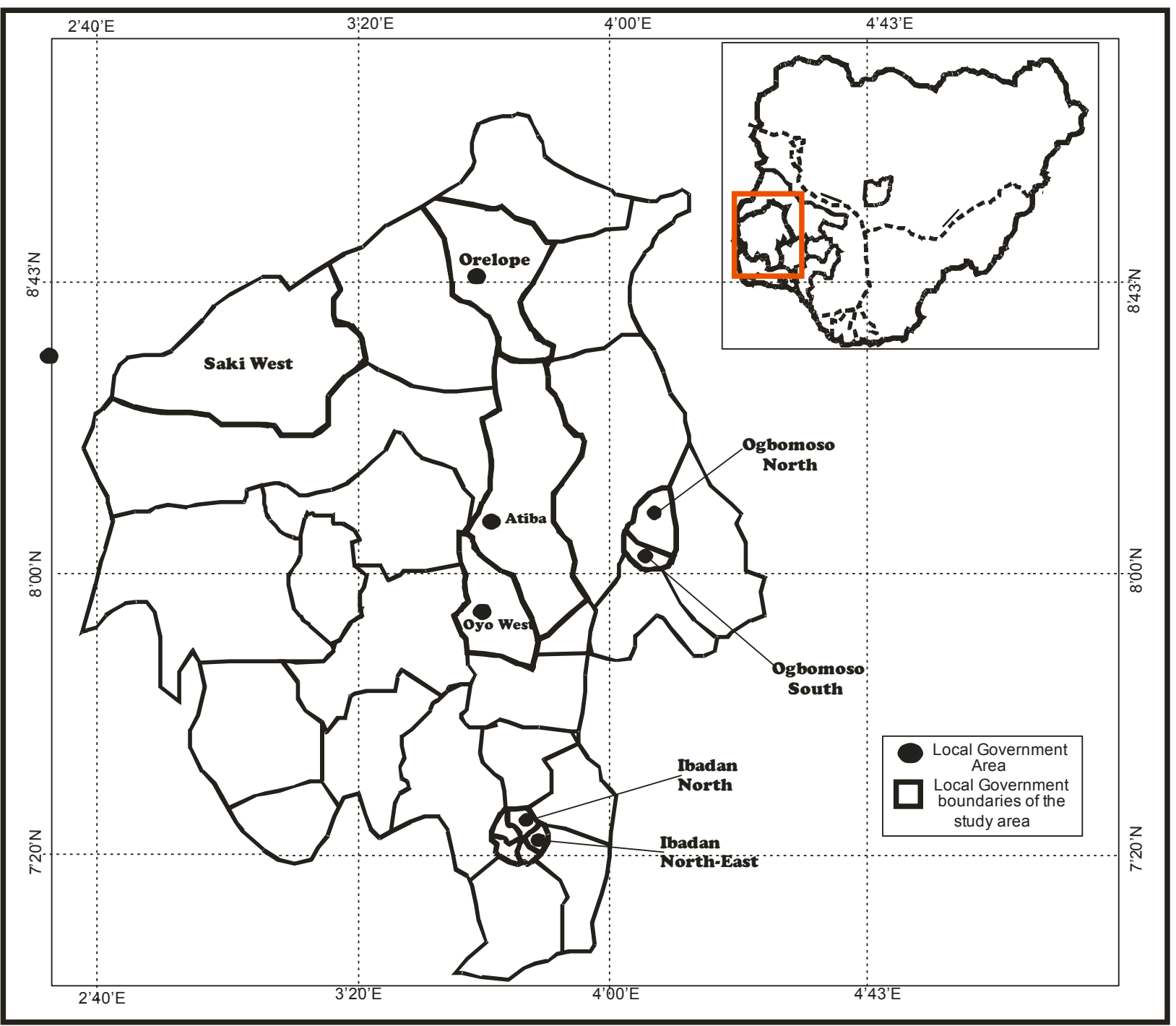

FIGURE 1: MAP OF OYO STATE

COLLECTION OF PRIMARY DATA

Questionnaires were used to conduct oral interviews for market sellers on the type of pesticide use, the mode of application, choice for choosing pesticide and length of storage after pesticide application. 


\section{COLLECTION OF SAMPLES FOR CHEMICAL ANALYSIS}

Three food samples (yam chips, cowpea and smoked fish) were collected at the above mentioned markets from fifteen randomly selected merchants. From each market, a kilogram of each food item was collected from each merchants and mixed together, out of which $2 \mathrm{~kg}$ sample was taken for laboratory analysis.

PREPARATION OF SAMPLE FOR EXTRACTION

These samples were carefully crushed with mortar and pestle to expose the inner portions of the food samples. A portion of the crushed sample $(50 \mathrm{~g})$ was weighed using a sensitive weighing balance and tied in filter paper for the extraction. Reflux extraction was done with the use of Soxhket extractor. The samples were assembled in the extractor. After extraction, the solvent was removed by means of rotary evaporator yielding the extracted compound. The non-soluble portion of the extracted solid was discarded.

\section{GAS LIQUID CHROMATOGRAPHIC ANALYSIS}

The extract was then analysed by Gas Liquid Chromatography Mass Spectrometer (GC-MS) using Ai Cambridge Ltd. Model GC94FID operated at these conditions: FID column $12 \mathrm{ft}$ x $2 \mathrm{~mm}$ I.D wit OV17 on $100 / 120$ H.P. chromosorb G: N2 at $30 \mathrm{cc} / \mathrm{min}$, injector $190^{\circ} \mathrm{C}$, column, $180^{\circ} \mathrm{C}$ Detector $200^{\circ} \mathrm{C}$. Standards of all pesticides of all pesticide detected were prepared at $100 \mu \mathrm{I} / \mathrm{ml}$ using Hamilton Microsyringe $10 \mu$ i.e $10 \mathrm{ppm}$ of appropriate standards were first injected into the GC to establish their retention times. Identification of the unknown sample was based on a comparison of the retention time of the unknown component with that obtained from a known standard compound analyzed under identical conditions according to [13].

DATA ANALYSIS

Data collected from the questionnaire were summarised using frequencies percentage and description statistics, with the aid of the Statistical Package for Social Sciences (SPSS version 15.0).

\section{RESULTS}

Most of the Respondents sell; maize, yam chips, cowpea and smoked fish $(30.8 \%, 27.5 \%$, $29.2 \%$ and $12.5 \%$ respectively) (Table 1 ). Table 2 shows the pesticide use and its duration in the selected markets of Oyo State. Most of the respondents 66 (55.0\%) used phostoxin, 26 (21.6\%) of the respondents does not know the type of pesticide used or those not use pesticide at all to preserve the food produce, $24(20.0 \%)$ of the respondents use DDforce while $4(3.3 \%)$ of the respondents use dichlorvos. Some of the respondents $35(29.2 \%)$ does not have any reason for choosing the selected pesticide. Thirty four $(28.7 \%)$ of the respondents chose pesticide to use based on custom, about 30 $(25.0 \%)$ of the respondents chose the selected pesticide based on availability and $21(17.5 \%)$ of the respondents used the selected pesticide due to its ease of application.

About 59 (49.1\%) of the respondents stored their food produce for less than a month after pesticide application, $30(25.0 \%)$ of the respondents stored food produce for more than 6 months after application, $16(13.3 \%)$ respondents stored food produce for 3 months while least proportion of respondents stored for 2 months (7.5\%), 1 month (4.2\%) and 4-6 months $(0.8 \%)$ after application. Fifty-nine (49.2\%) respondents applied pesticide by fumigation, $31(25.8 \%)$ of the respondents did not know the method used, 27 (22.5\%) of the respondents applied by spraying while least proportion of the respondents $3(2.5 \%)$ applied pesticide by retting.

From food samples obtained from Araada Market, Ogbomoso, eight compounds were detected in yam chips, $3(37.5 \%)$ of the compounds were alkane, $3(37.5 \%)$ of the compounds were organochlorine while 2 (25\%) of the compounds belongs to pyrethrum (Table 3 ). Four compounds were detected in cowpea of which $2(50 \%)$ of the compounds were alkanes, $1(25 \%)$ belongs to akyl and organochlorine. An aromatic compound was detected in smoked fish sample. In Owode Market, Igboho, 32 compounds were detected in yam chips of which $11(34.38 \%)$ of the compounds belong to alkane group, $3(9.38 \%)$ of the compounds were organochlorine, $4(12.5 \%)$ of the compounds were pyrethrum, $5(15.63 \%)$ compounds were esters, $3(9.38 \%)$ of the compounds belong to alcohol group (Alkanol and Nerol), camphor, sesquiterpene, alkene, alkanal, cyclo compound and Glaucic 
acid has 1 compound each. Eleven compounds were detected in cowpea sample, 9 (81.82\%) compounds were alkane, organochlorine and zeatin had 1 compound each. Twenty four compounds were detected in fish sample, $7(29.17 \%)$ compounds belong to organochlorine, $7(29.17 \%)$ compounds were alkane, $2(8.33 \%)$ of the compounds were pyrethrum and aldehyde, $5(20.83 \%)$ of the compounds belongs to esters while 1 compound belongs to alkanoate. From food samples in Ajegunle Market, Oyo, eight compounds were detected in yam chips, 7 (87.5\%) of the compounds are alkane and $12.5 \%$ of the compounds belongs to organochlorine. Twenty two compounds were detected in cowpea sample, $15(68.18 \%)$ of the compounds were alkane, $1(4.55 \%)$ of the compounds belongs to organochlorine while alkene and ester has $2(9.09 \%)$ compounds each. Twenty eight compounds were detected in fish sample, $11(39.29 \%)$ of the compounds belongs to alkane group, $6(21.43 \%)$ compounds were organochlorine, $3(10.71 \%)$ of the compounds were pyrethrum, while acid, ester, alkanal and alkanol has 1 compound each. For food samples obtained from Oje Market, Ibadan, ten compounds were detected in yam chips, 4 (40\%) of the compounds were alkane, $3(30 \%)$ of the compounds belong to esters while alkene and alkyne has $1(10 \%)$ compound each. About 29 compounds were found in fish sample, 14 (48.28\%) of the compounds are alkanes, $5(17.24 \%)$ of the compounds were alkene, $2(6.90 \%)$ compounds belongs to organochlorine and phenols while ester, alkanol, pyrethrum and acid has 1 compound each. 21 compounds were found on cowpea, $14(66.67 \%)$ of the compounds belong to alkane group, 2 $(9.52 \%)$ of the compounds were ester while organochlorine, acid and alkanol has $1(4.76 \%)$ compounds each.

Table 1: Common foodstuff available in the eight selected markets during the period of study

\begin{tabular}{cc}
\hline VARIABLES & FREQUENCY(n=120) \\
\hline Sampled produce & $37(30.8 \%)$ \\
Maize & $33(27.5 \%)$ \\
Yam chips & $35(29.2 \%)$ \\
Cowpea & $15(12.5 \%)$ \\
Smoked fish & \\
\hline
\end{tabular}

FREQUENCY $(\mathbf{n}=120)$

Table 2: Pesticides used and storage duration of produce in the selected markets of Oyo State

VARIABLES

FREQUENCY

$(\mathbf{n}=120)$

TYPES OF PESTICIDE USED

Phostoxin

$66(55.0 \%)$

DD force

$24(20.0)$

Dichlorvos

$4(3.3 \%)$

Not applicable

$26(21.6 \%)$

REASONS FOR CHOOSING THE PESTICIDE

$34(28.3 \%)$

Custom

$30(25.0 \%)$

Availability

$21(17.5 \%)$

Ease of application

$35(29.2 \%)$

DURATION OF STORAGE AFTER APPLICATION

$59(49.1 \%)$

$<1$ month

1 month

$5(4.2 \%)$

2 months

$9(7.5 \%)$

3 months

$16(13.3 \%)$

4-6 months

$1(0.7 \%)$

$>6$ months

$30(25.0 \%)$

MODE OF APPLICATION

$59(49.2 \%)$

Fumigation

$27(22.5 \%)$

Spraying 


\begin{tabular}{cc}
\hline Retting & $2(1.7 \%)$ \\
Not applicable & $31(25.8 \%)$ \\
DURATION OF STORAGE BEFORE PESTICIDE APPLICATION & \\
Immediately & $1(0.8 \%)$ \\
After 1 month & $5(4.2 \%)$ \\
Nil & $114(95.0 \%)$ \\
\hline
\end{tabular}

Table 3: Abundance of Pesticide residues in various food sampled in the selected markets of Oyo State

\begin{tabular}{|c|c|c|c|c|c|c|c|c|c|c|c|c|}
\hline \multirow{2}{*}{$\begin{array}{c}\text { Chemical } \\
\text { group }\end{array}$} & \multicolumn{3}{|c|}{ Araada Market (Ogbomoso) } & \multicolumn{3}{|c|}{ Owode Market (Igboho) } & \multicolumn{3}{|c|}{ Ajegunle Market (Oyo) } & \multicolumn{3}{|c|}{ Oje Market (Ibadan) } \\
\hline & Cowpea & $\begin{array}{l}\text { Yam } \\
\text { chips }\end{array}$ & Fish & Cowpea & $\begin{array}{l}\text { Yam } \\
\text { chips }\end{array}$ & Fish & Cowpea & $\begin{array}{l}\text { Yam } \\
\text { chips }\end{array}$ & Fish & Cowpea & $\begin{array}{l}\text { Yam } \\
\text { chips }\end{array}$ & Fish \\
\hline Pyrethrum & - & & - & 4 & - & 2 & - & - & 3 & - & 1 & - \\
\hline Akyl & 1 & - & - & $=$ & - & $=$ & - & - & - & - & & \\
\hline Organo chlorine & 1 & 3 & - & 3 & 1 & 7 & 1 & 1 & 6 & - & 2 & 1 \\
\hline Alkane & 2 & 3 & - & 11 & 9 & 7 & 7 & 15 & 11 & 4 & 14 & 14 \\
\hline $\begin{array}{l}\text { Aromatic } \\
\text { hydrocarbon }\end{array}$ & - & - & 1 & - & - & - & - & - & - & - & - & 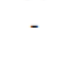 \\
\hline Camphor & - & - & - & 1 & - & - & - & - & - & - & - & - \\
\hline Ester & - & - & - & 5 & - & 6 & - & 2 & 1 & 3 & 1 & 2 \\
\hline Cyclo compounds & - & - & - & 1 & - & - & - & - & - & - & - & - \\
\hline Alkanol & - & - & - & 3 & - & - & - & - & - & - & - & - \\
\hline Zeatin & - & - & - & - & 1 & - & - & - & - & - & - & - \\
\hline Alkene & - & - & - & 1 & - & - & - & 2 & - & 1 & 5 & - \\
\hline Glaucic Acid & - & - & - & 1 & - & - & - & 1 & 1 & - & 1 & 1 \\
\hline Sesquiterpene & - & - & - & 1 & - & - & - & - & - & - & - & - \\
\hline Alkanal & - & - & - & 1 & - & - & - & - & 1 & - & - & - \\
\hline Aldehyde & - & - & - & - & - & 2 & - & - & - & - & - & - \\
\hline Alkyne & - & - & - & - & - & - & - & - & - & 1 & - & - \\
\hline Alkanol & - & - & - & - & - & - & - & - & 1 & - & 1 & 1 \\
\hline Phenol & - & - & - & - & - & - & - & - & - & - & 2 & \\
\hline
\end{tabular}

Numbers different form of plant residue in each market

\section{DISCUSSION}

Maize, yam chips and cowpea were the major staple food in the markets, this is in accordance with the report of [14] (2010) which states that the most staple foods are derived from either cereals such as maize, rice or root tubers such as yam and yam products or legumes such as cowpea and groundnut. Majority of the respondents use phostoxin which can be used as rodenticide or fumigants in preserving their produce. This was in line with what $[15,16]$ reported that, the commonly used aluminium phosphide are phostoxin, Quickphos and Fumitox. The most commonly used Organophosphates include; DDforce, chlorpyrifos, parathion and malathion. Majority of the respondents store produce for less than a month before disposing it to the consumer, which could cause food poisoning or contamination. This might be because many do not understand the concept of withholding period which is the maximum length of time that must elapse or a person must wait after application of pesticide on food crop before it is safe for consumption. It was reported that 20 fast food outlets were closed in Nigeria because of fatalities traced to pesticide residue in their food [17].

In all the markets visited from the survey, different chemicals (alkane, organochlorine, pyrethrum, ester, akyl, alkene, sesquiterpene, alkanol, alkanal, phenols, acids) were detected in all the food samples ready for sale to the consumers. Cowpea and fish samples have the highest number of alkane in all the market sampled, although studies have investigated alkane in the environment [18;19], dust [20], human serum [21], human milk [22], and animal tissues [23,24], few have examined alkane contamination of food. Toxicity studies suggest that the alkane is an endocrine disruptor and developmental neurotoxicant; specifically, some alkane compound have been associated with changes in rat thyroid systems [25,26], altered function of human natural killer cells [27;28], and neurotoxic effects such as decreased fine manipulative abilities and lower attention in children [29]. 
Organochlorine has highest proportion in fish samples and yam chips. Many studies conducted so far have revealed the presence of detectable level of pesticide especially organochlorines in fruits, vegetables, fish and fish products. The studies pointed out that majority of the samples contaminated by chlorinated pesticides exceeded the maximum limits which could cause pesticide hazard to the consumer [30,31]. It was observed that organochlorines persisted in the environment long after being banned and may be involved in the causation of breast cancer as a result of estrogenic activity [32]. Alkene, alkyne, esters, acids, phenols and pyrethrum were found in small quantity in all the food samples taken in all sampled markets.

\section{CONCLUSION AND RECOMMENDATION}

Most of the respondents deal in selling maize, cowpea and yam chips and the most common insecticide used were phostoxin and DDforce. Many of the respondents sell not long after application of insecticide to their products without considering the withholding period. It can be concluded that in all the food samples assessed in the visited markets, cowpea and fish samples have the highest number of alkane and organochlorine was high in fish samples and yam chips. There is therefore, the need to educate produce merchants on safe use of pesticides in preservation of consumable meant for immediate sale.

\section{References}

[1]. A. Nasiru, The effect of insecticides and airtight storage on the storability of cowpea in Maiduguri, Nigeria, African Journal of General Agriculture, (2009) 6: 1p.

[2]. H. Jelle, The storage of tropical agricultural product. Agrodok 31: Agromisa Foundation, Wageningen, (2003).

[3]. F. W. T. Penning de Vries, Food security we are losing ground fast. In: Noesberger, J., Geiger, H.H. and Struik, P.C. (Eds), Crop Science: Progress and Prospects, (2001) 1 - 14.

[4]. S. G. Jonathan, and T. B. Olowolafe, Studies on nutrient contents and microorganisms associated with dodo Ikire a plantain snack from Western Nigeria, NISEB J., (2001)1 (1): 27 -30 .

[5]. B. C., Adebayo -Tayo, A. A. Onilude, A. A. Ogunjobi, J. S. Gbolagade and Oladapo, M. O., Detection of fungi and aflatoxin in shelved bush mango seeds (Irvinga spp.). Stored for sale Uyo, Nigeria, Electron. J. Environ. Agric. Food Chem., (2006) 5(5): 1569-1574.

[6]. O. S. Olabode, G. O. Adeshina and T. R. Olapeju, A survey of Agricultural Chemicals Available to Farmers in South Western Nigeria, International Journal of Agricultural Economic and Rural Development, (2011) 4 (1).

[7]. J. Cooper, and H. Dobson, The benefits of pesticide to mankind and the environment, Crop Protection, (2007) 26: 1337 - 1348.

[8]. G. O. Otitodun, G. Opit and E. O. Okonkwo, Efficacy of Nigeria - derived diatomaceous earth, botanical insecticides, and riverbed sand against Sitophilus oryzae (Coleoptera: Curculionidae) and Rhyzopertha dominica (Coleoptera: Bostrichdae) on wheat. Entomological Society of America, ESA annual meetings online www.esa.confex.com. (2012)

[9]. E. D. Richter, Acute Human Pesticide Poisonings. Encyclopedia of Pest Management, Taylor and Francis, (2002) 3-6.

[10]. M. Eddleston, N. A. Buckley, P. Eyer and A. H. Dawson, Management of acute organophosphorus pesticide poisoning, Lancelet, (2008) 16; 597 - 607.

[11]. H. M. Menair and E. J. Bonelli, Basic gas chromatography. Varian aerograph. $5^{\text {th }}$ Ed. Consolidated printer, Berleley, Califonia (1969): 143p 
[12]. I. Shaibu, NAFDAC bans 30 agrochemical products. Vanguard, May 14, 2008. www.allafrica.com. (2008)

[13]. The Guardian, Red alert over rising cases of food poisoning, deaths. http://www.ngrguardiannews.com/2015/03/red-alert-over-rising-cases-of-food-poisoningdeaths. Feb 19th, 2014. Accessed on Jun $19^{\text {th }}, 2015$

[14]. UN/FAO, Agricultural and consumer Protection. Dimensions of Need-Staples: What do people eat? (2010)

[15]. A. Buckle, Rodenticides Ullman's Encyclopedia of Industrial Chemistry, Weinhein: WileyVCH. (2005)

[16]. M. R. Bomer, J. Coble, A. Blaire, Malathion Exposure and the incidence of cancer in the Agricultural Health Study, American Journal of Epidemiology, (2007) 166(9): 1023 - 34.

[17]. A. Chikwe, NAFDAC axes 20 fast food outlets. Task operators on good hygienic Practices, Tuesday, July 6, 2010. www.nigerianbestforum.com

[18]. R. J. Law, D. Herzke, S. Harrad, S. Morris, P. Bersuder and C. R. Allchin, Levels and trends of HBCD and BDEs in the European and Asian environments, with some information for other BFRs, Chemosphere, (2008) 73: 223 - 241.

[19]. M. Haukas, K. Hylland, J. A. Berge, T. Nygård and E. Mariussen, Spatial diastereomer patterns of hexabromocyclodo- decane (HBCD) in a Norwegian fjord, Sci Total Environ, (2009) 407: $5907-5913$.

[20]. S. Harrad, and M. Abdallah, Personal exposure to HBCDs and its degradation products via ingestion of indoor dust, Environ Int, (2009) 35: 870 - 876.

[21]. L. Roosens, Abdallah MA-E, Harrad S, Neels H, Covaci A. Exposure to hexabromocyclododecanes (HBCDs) via dust ingestion, but not diet, correlates with concentrations in human serum: preliminary results. Environ Health Perspect (2009) 117:1707-1712.

[22]. J. J. Ryan, B. C. Wainman, A. Schecter, J. Moisey, I. Kosarac, W. F. Sun, Trends of the brominated flame retardants, PBDEs and HBCD, in human milks from North America. Organohalogen Compounds, (2006) 68:778-781.

[23]. B. N. Zegers, A. Mets, R. van Bommel, C. Minkenberg, T. Hamers and J. H. Kamstra, Levels of hexabromo cyclo- dodecane in harbor porpoises and common dolphins from western European seas, with evidence for stereoisomer- specific biotransformation by cytochrome P450. Environ Sci Technol, (2005) 39: 2095 - 2100.

[24]. B. Johnson-Restrepo, D. H. Adams, K. Kannan, Tetrab romo- bisphenol A (TBBPA) and hexabromocyclododecanes (HBCDs) in tissues of humans, dolphins, and sharks from the United States, Chemosphere, (2008) 70: 1935 - 1944.

[25]. Y. Saegusa, H. Fujimoto, G. H. Woo, K. Inoue, M. Takahashi and K. Mitsumori, Developmental toxicity of brominated flame retardants, tetra bromo bisphenol A and 1,2,5,6,9,10-hexabromocyclododecane, in rat offspring after maternal exposure from midgestation through lactation. Reprod Toxicol, (2009) 28: 456 - 467.

[26]. V. Palace, B. Park, K. Pleskach, B. Gemmill and G. Tomy, Altered thyroxine metabolism in rainbow trout (Oncorhynchus mykiss) exposed to hexabro mocyclo dodecane (HBCD). Chemosphere, (2010) 80: 165 - 169.

[27]. N. C. Hinkson, and M. M. Whalen, Hexabromocyclododecane decreases the lytic function and ATP levels of human natural killer cells, J Appl Toxicol, (2009) 29: 656 - 661. 
[28]. N. C. Hinkson, and M. M. Whalen, Hexabromocyclododecane decreases tumor-cell-binding capacity and cell-surface protein expression of human natural killer cells, J Appl Toxicol, (2010) 30: $302-309$.

[29]. E. Roze, L. Meijer, A. Bakker, K. N. J. A Van Braeckel, P. J. J. Sauer and A. F. Bos, Prenatal exposure to organohalogens, including brominated flame retardants, influences motor, cognitive, and behavioral performance at school age. Environ Health Perspect, (2009) 117: 1953 - 1958.

[30]. F. Botchway, Analysis of pesticides residues in Ghana's Exportable Cocoa. Higher Certificate Project, Institute of Science and Technology, London. 2000

[31]. D. K. Essumang, G. K. Togoh and L. Chokky, Pesticide residues in the water and fish (Lagoon Tilapia) samples from Lagoons in Ghana, Bulletin of the Chemical Society of Ethopia, (2009) 23 (1): $19-27$.

[32]. E. E. K. Clarke, L. S. Levy, A. Spurgeon and I. A. Calvert, The Problems Associated with Pesticide Use by Irrigation Workers in Ghana, Occupational Medicine, (1997) 47 (5): $301-$ 308. 